Journal of Social Sciences 6 (4): 529-531, 2010

ISSN 1549-3652

(C) 2010 Science Publications

\title{
Cyber Bullying: Challenges and Strategies Faced by Juvenile Police Officers
}

\author{
Ken Thaxter \\ Department of Police, Town of West Bridgewater, \\ West Bridgewater, Massachusetts, USA
}

\begin{abstract}
One of the challenges of teaching pre-teens about the internet is their varying degrees and levels of involvement. The juvenile police officer brings a solid understanding of the laws as well as a strong knowledge of safety issues to the classroom, making them an excellent educational resource. Officers can utilize an educational approach with parents and students in which they define what cyber bullying is and, importantly, demonstrate that definition by describing real cases that I and other officers have addressed. This approach focused both on the effect that cyber bullying has on the victims and the impact of the online behavior on the atmosphere and climate at the school. Students and parents also need to learn about the potential consequences for the perpetrator. Finally, an important method for bridging varying degrees of involvement in bullying is to emphasize that all students play a role in cyber bullying prevention-not merely those who perpetrate it or are victimized by it. That lesson is accomplished through discussions about strategies that bystanders can use to intervene.
\end{abstract}

Key words: Cyber bullying, online bullying, school resource officer, juvenile police officers

\section{INTRODUCTION}

Education, intervention and adjudication are the main strategies for juvenile police officers handling the issue of cyber bullying in schools. The juvenile police officer brings a solid understanding of the laws as well as a strong knowledge of safety issues to the classroom, making them an excellent educational resource. Many police officers, parents and educators are intimidated by the technological aspects of cyber bullying (Juvonen and Gross, 2008). I approach the topic by addressing the bullying aspect and its relation to the overall safety of the School.

My educational approach with parents and students defines what cyber bullying is and demonstrates that definition by describing both cases that I and other officers have addressed. I then focus on the effect that cyber bullying has on the victims and on the atmosphere and climate at the school, as well as the potential consequences that it has for the perpetrator. Most importantly, strategies for bystanders to intervene are discussed. I stress the importance of reporting cyber bullying to adults and the mechanisms for doing this.

One of the challenges of teaching pre-teens about the internet is their varying degrees and levels of involvement. It can be a struggle to attempt to "reach" students by engaging them in activities in which they are interested, because engaging them where their interests lay may unintentionally promote inappropriate behavior. For example, in one lesson, I asked a group of students to raise their hands if they had a face book page. A majority of the 6th grade students, who range in age from 11-12, responded that they did. I then asked them to examine the profile page which I had set up for our drug and alcohol program that I teach, recommending that they join my group and encourage their parents to also do so. My intent was to have a community clearing-house for important safety information as well as establishing a communication mechanism that is familiar and comfortable for students.

Following the presentation, however, I had a parent contact me with some concerns. The parent raised an important issue, expressing the very valid concern that my presentation might inadvertently encourage preteens to participate on social networking websites such as face book (where the minimum age for use is 13, despite widespread use by younger children). They also asked if I felt that their personal reluctance to allow their child access to face book could be causing their child problems with regard to peer pressure and "fitting in". This contact prompted me to reconsider my discussion of the issue in my student presentation and thereafter I pointedly reminded students that face book is intended for use by high school and college students (and older adults, of course). Because face book is not 


\section{J. Social Sci., 6 (4): 529-531, 2010}

intended for pre-teens, I explained that their participation in Facebook needed to be with the full knowledge of and in cooperation with their parents and that their parents are the final decision makers with regards to their internet communications.

Intervention is also a very necessary and important reality for juvenile police officers. Despite the fact that many acts of cyber bullying actually occur outside of the school property and hours, the behavioral impact of cyber bullying often spills over into the school climate. While it can be tempting to leave such incidents alone, unfortunately, there are numerous examples of students who were bullied, only to violently act out in school or commit suicide. Complicating intervention is the issue of jurisdiction. In helping to determine appropriate jurisdiction case by case, it is important that school administration and law enforcement form a partnership and exchange information. Ideally, a written memorandum of understanding should be developed between schools and local law enforcement which addresses the specific issue of cyber bullying (Lexington Public Schools, 2007; Sumalatha and Ramakrishnaiah, 2004).

It is often the case that law enforcement may assist schools in resolving incidents successfully. In a recent example, the parents of a sixth grade girl reported to the police department that their daughter was involved in an on-line chat at home when several other unidentified students referred to her as a virgin and suggested that they have sex with her, causing her fear and distress. Not being technologically proficient, the parents took a digital photograph of the computer monitor and brought it my attention. I was able to work with school personnel to determine the identities of the other students by their screen names. We then met with these students and parents resulting in no further incidents. In this case, the initial contact was made to police; however, it was handled in the school environment.

In other cases schools may need more involvement from law enforcement to successfully resolve an incident. In such a recent case, a 17 year old student created a my space page using the identity of a former teacher who had recently changed professions and who did not have his/her own legitimate profile. The publicly-available area of the profile featured an image of the teacher as well as some identifying information and was designed to present itself as a legitimate profile authored by the former teacher themselves. However, an area of the profile which was designated "private" (that is, available only to those whom the author permitted viewing) featured accusations of sexual acts and deviances. The private area of the page was also being used as a portal or straw site for a group of students to communicate and tight control was kept on who could become a friend. A student who had been allowed access to the private area realized the potential harm and informed the school administration, who in turn, contacted my office. The reporting student provided printouts of several days of communications.

Although used mostly in cases of credit theft, under Massachusetts law, a person who "poses as another... with the purpose of harassing that person" has committed the crime of identity fraud (General Laws of Massachusetts, 2010a). In this case, I contacted the victim, who was unaware of the my space page, but understandably expressed great concern as they were currently in the process of interviewing for several positions and feared the fraudulent profile might impact their employment opportunities. I interviewed the student, who admitted (in the face of the evidence) to creating the page. The student further added that it was "just a joke and they didn't mean anything by it", although they did acknowledge disliking this particular teacher. I explained to the student and the student's parents that charges could be filed. Legally, since the student was now aware of the victim's concern, any further actions by the student would constitute harassment (General Laws of Massachusetts, 2010c). In light of this information and with additional assistance from the school and further outreach to the victim, a full apology was arranged and accepted.

Adjudication is the final strategy that police use when dealing with cyber bullying. Bringing charges against students who cyber bully should only be considered when education and intervention have been attempted and have failed. Prosecutorial discretion should be used based on the specifics of the offender and victim and the overall effect on the school climate. When the decision is made to pursue charges, the goal with juveniles is rehabilitation by working with juvenile courts through diversion programs.

There are several challenges to adjudication faced by police. First, cyber bullying investigations of students under 17 years old that could result in criminal charges have the potential of triggering Miranda warnings and therefore require the presence of a parent or interested adult. Law enforcement must also be careful that while in partnership with the schools they do not make the administration an agent of law enforcement during investigations. This could result in important information being inadmissible in court.

Second, officers need to maintain a working knowledge of the latest technology and social networking sites to successfully investigate cyber bullying cases, which can be a challenge among police officers who are intimidated by technological advances 
(Juvonen and Gross, 2008). Unlike conventional bullying, cyber bullying leaves a trail. Verbal threats, taunting and fighting on the playground may be difficult to investigate, but online bullying produces an electronic footprint. Despite the perceived anonymity of the internet, law enforcement has many tools to investigate and track cases cyber bullying.

Third, similar to many other state, Massachusetts has no specific law addressing cyber bullying. Our legislators, however, have recently amended several laws to include the phrase "electronic communications". This allows law enforcement to use existing laws to address cyber bullying. For example, criminal harassment laws can be used in cases where texting is used to threaten or bully a victim. Additionally, as I outlined above, identity fraud laws can be utilized in cases where web pages are created using another person's identity. Also, the felony of malicious destruction of property was amended to include electronically stored data and can be used in cases of hacking into web sites (General Laws of Massachusetts, 2010b).

\section{CONCLUSION}

The role of the juvenile police officer in a post Columbine era has changed from reactive to proactive. Addressing the problem of cyber bullying through early education and intervention, as opposed to adjudication after the fact, is vital in securing a safe school environment. Changing technology in the face of a sometimes slow to respond criminal justice system and parental apathy arising from the lack of understanding of the impact of cyber bullying, are both issues that police officers who work in the schools must face.

\section{REFERENCES}

General Laws of Massachusetts, 2010a. Use of personal identification of another; identity fraud; penalty; restitution. The General Court. http://170.63.97.68/legis/laws/mgl/266-37e.htm

General Laws of Massachusetts, 2010b. Personal property; malicious or wanton injuries. The General Court. http://170.63.97.68/legis/laws/mgl/266-127.htm

General Laws of Massachusetts, 2010c Criminal harassment; punishment. The General Court. http://www.mass.gov/legis/laws/mgl/265-43a.htm

Juvonen, J. and E.F. Gross, 2008. Extending the school grounds-bullying experiences in cyberspace. J. School Health, 78: 496-505. DOI: 10.1111/j.17461561.2008.00335.x

Lexington Public Schools, 2007. Memorandum of understanding between Lexington public schools and Lexington police department. Public Protection, Anti-Terrorism, Corruption and Technology Unit. http://lps.Lexingtonma.org/Current/LPSPoliceMO A.pdf

Sumalatha, K. and D. Ramakrishnaiah, 2004. Sex bias in secondary school social studies textbooks: A case study in India. Am. J. Applied Sci., 1: 62-63. DOI: $10.3844 / .2004 .62 .63$ 